\title{
Groundwater Quality Assessment for Drinking and Agricultural Purposes in Tabriz Aquifer, Iran
}

\author{
Esmaeil Asadi 1, Mohammad Isazadeh 1, Saeed Samadianfard 1, Mohammad Firuz Ramli 2, \\ Amir Mosavi 3,4, Shahaboddin Shamshirband 5,6,*, Kwok-Wing Chau ${ }^{7}$
}

1 Department of Water Engineering, University of Tabriz, Tabriz, Iran; es-asadi@tabrizu.ac.ir ${ }_{L}$ mohammadisazade@gmail.com, s.samadian@tabrizu.ac.ir

2 Universiti Putra Malaysia, Department of Environmental Sciences, Serdang, Malaysia; firuz@env.upm.edu.my

3 Queensland University of Technology, Faculty of Heslth, Victoria Park Road, Queensland 4059, Australia

4 Kando Kalman Faculty of Electrical Engineering, Obuda University, 1034 Budapest, Hungary: amir.mosavi@kvk.uni-obuda.hu

5 Department for Management of Science and Technology Development, Ton Duc Thang University, Ho Chi Minh City, Vietnam

6 Faculty of Information Technology, Ton Duc Thang University, Ho Chi Minh City, Vietnam

7 Department of Civil and Environmental Engineering, Hong Kong Polytechnic University, Hung Hom, Hong Kong, China; dr.kwok-wing.chau@polyu.edu.hk

* Corresponding author, Email: shahaboddin.shamshirband@tdtu.edu.vn

\begin{abstract}
The key goal of the current study was to determine suitable areas of water pumping for drinking and agricultural harvest in Tabriz aquifer, located in East Azerbaijan province, northwest Iran. In the study area, groundwater is the key foundation of water for drinking and farming requirements. Groundwater compatibility study was conducted by analyzing Electrical conductivity (EC), Total dissolved solids (TDS), Chloride (Cl), Calcium (Ca), Magnesium (Mg), Sodium (Na), Potassium (K), Sulfate $\left(\mathrm{SO}_{4}\right)$, Total hardness $(\mathrm{TH})$, Bicarbonate $\left(\mathrm{HCO}_{3}\right), \mathrm{pH}$, carbonate $\left(\mathrm{CO}_{3}\right)$ and Sodium Adsorption Ratio (SAR) obtained from 39 wells in the period of 2003 to 2014. For this purpose, the Water Quality Index (WQI) and irrigation water quality (IWQ) index is respectively utilized. The WQI index zoning exposed that the groundwater of the study area for drinking purposes is categorized as excellent, good and poor water. Most drinking water harvested for urban and rural areas are in the class of 'excellent water'. IWQ index average for the study area was in the range of 25.9 to 34.55 . The results revealed that about 37 percent $\left(296 \mathrm{~km}^{2}\right)$ of groundwater has high compatibility, and 63 percent of the study area $\left(495 \mathrm{~km}^{2}\right)$ has average compatibility for agricultural purposes. The trend of IWQ and WQI indexes demonstrates that the groundwater is getting worse over time.
\end{abstract}

Keywords: water quality index (WQI); groundwater quality; modeling irrigation water quality; Tabriz aquifer; water resource management

\section{Introduction}

About two-third of the earth planet is enclosed by the life-giving liquid which is named water, though 1 percent of the whole amount consists of drinking water which is appropriate for human consumption. It is obvious that the supreme use of water is for human consumption for responding to his needs. If people use water resources with caution, adequate water with decent quality is sufficient for the existing population (Hashmi et al., 2009). Farming is a prevailing segment of the worldwide economy (FAO, 
1994). Farming is notable as the biggest client of crisp water and a noteworthy reason for the debasement of surface and groundwater assets and quality (FAO, 1994).

Groundwater assets are vital for financial improvement, particularly in parched and semi-bone-dry areas (Tlili-Zrelli et al., 2013). The quality of water is identified as the normal, physical and compound condition of the water, and additionally, any adjustment that may have been initiated by anthropogenic action (Venkateswaran et al., 2011; Jafar Ahamed et al., 2013; Khan et al., 2012; Salahat et al., 2014).

The groundwater quality is the consequence of every one of those procedures and responses that follow up on water from the minute it is gathered in the climate until the time it is stored by a well, which is regularly controlled by different physicochemical attributes (Arumugam and Elangovan, 2009).

The combined effects of populace development and extreme harvestation of groundwater have initiated broad exhaustion and corruption of groundwater assets (Amiri et al., 2014). Moreover, it is clear that the quality of agricultural water has an influence on the quality of the soil and accordingly on the harvests which are developed on the soil. The interest in a farming area and the produces items has advanced quickly in the most recent century due to populace development. What's more, specialists mention that some elements, for example, more urban areas, more industrialized spaces, inadequate management of the lands and ecological contamination has forced extra weight on prodection of agricultural items (Tanji, 1990; Kwiatkowski et al., 1995). Therefore, viable exploitation of both the farming area and the irrigation water has turned into a crucial part, if not the essential goal, of several agrarian improvement and administration designs. Hence, evaluating the quality of groundwater is imperative. Conventional assessment of groundwater quality is straightforward yet point by point in view of the individual parameters (Mohebbi et al., 2013). Therefore, it is not adequate to give a precise representation of water quality. Hence, water quality indexes have been produced for condensing water quality information in an effectively expressible and justifiable configuration (Saeedi et al., 2010; Ramakrishnaiah et al. 2009). Typically, the nature of a water system sources is related with its (a) saltiness amount, (b) penetration or porousness danger, (c) particular poisonous ions quality, (d) trace elements harmfulness; and, (e) different various influences to defenseless products. It should be noted that these dangers or negative effects could happen simultaneously, which makes assessing harder to accomplish (Simsek and Gunduz, 2007). Simsek and Gunduz (2007) suggested an irrigation water quality (IWQ) list to characterize water system quality which was based on the five risk groups that were specified above on touchy harvests.

The IWQ index is a strategy in which the linear blending of factors in a collection of water system quality that impact soil quality and harvest yield in a negative way (Adhikari et al., 2011). Numerous analysts have used this index for irrigation water system goal in light of diverse hydrochemical parameters due to its easiness of use and tought particularly for the nontechnical chief (Debels et al., 2005; Narany et al., 2014; Negm and Armanuos, 2016; Narany et al., 2016).

The key water quality index (WQI) was created by choosing and presenting an accumulation function (Simos et al., 2008). WQI index is utilized for qualitative zoning of the aquifers from the drinking aspect and also for determining the proper places of drinking water wells in a lots of research plots such as Effendi and Wardiatno 2015; Chen et al., 2015; Bodrud-Doza et al., 2016; Fijani et al., 2017; Schneider et al., 2016; Khan and Qureshi, 2018; Oyinkuro and Rowland, 2018.

A Geographical Information System (GIS) is a capable instrument for putting away, controlling, examining, and mapping spatial information for making decisions in a multiple regions at one time, which fundamental issues is a good example of it (Nampak et al., 2014). Many studies, such as Narany et al. (2014) and Manap et al. (2014) have effectively used GIS in demonstrating the distribution of water quality parameters. It is vital to preserve the sustainability of the aquifer's quality because groundwater 
in the study area is mostly implemented for agriculture and rural and urban drinking purposes. Therefore, for achieving a better understanding of procedures and the current form of groundwater quality in the study area, the following objectives were defined:

1) Identifying areas of aquifer feeding

2) Determining the WQI in an aquifer in the 24 time periods

3) Investigating the alterations in WQI for drinking water through the statistical period

4) Checking water quality status in tapping drinking wells and determining suitable locations for extracting drinking water

5) determining the IWQ in an aquifer in the 24 time periods

6) Investigating the variations in WQI for agricultural water during the statistical period

7) Checking water quality status in the agricultural wells and determining appropriate and inappropriate locations for extracting agricultural water

\section{Materials and Methods}

\section{Study Area}

The study area is Tabriz plain aquifer situated in East Azerbaijan province, Iran, with an area of $791 \mathrm{~km} 2$ (Figure 1). The most surface of the area is cultivated as apples, pears, apricots, peaches, cherries, green beans, leek, spinach and squash. About 40 percent (50 million cubic meters) of Tabriz city (with a population of 1.7 million) drinking water is also provided from the same aquifer. The mean yearly precipitation of Tabriz is nearly $290 \mathrm{~mm}$, which is very low contrasted with the world normal which is $800 \mathrm{~mm}$. The average temperature is $12.5^{\circ} \mathrm{C}$, and as indicated by the De Martonne aridity index, the district of study is categorized as a semiarid territory (Zarghami and Akbariyeh, 2012; Vaezihir and Tabarmayeh, 2015). Water assets of the aquifers start from rainfall, energizes from the streams, groundwater spill out of encompassing mountains, water system return streams water, city and industry wasted waters. Generally, there are three harvesting types in the study area, including harvest for supplying urban water, rural water and agriculture water. The number of urban, rural and agricultural water harvesting wells in the study area are 81,50 and is 3884 respectively. To provide the best quality drinking water, the position of Tabriz drinking water wells are embedded at the entry of the groundwater flows of the aquifer. Water depth in the area fluctuates between 1.5 and 186 meters and the overall average is 21 meters. Most of the groundwater flow entering to the aquifer is from the southern and southeastern highlands (Asghari Moghaddam and Allaf Najib, 2006; Barzegar et al., 2017). The highest water level is $2049.56 \mathrm{~m}$ and the lowest is $1262.8 \mathrm{~m}$. 


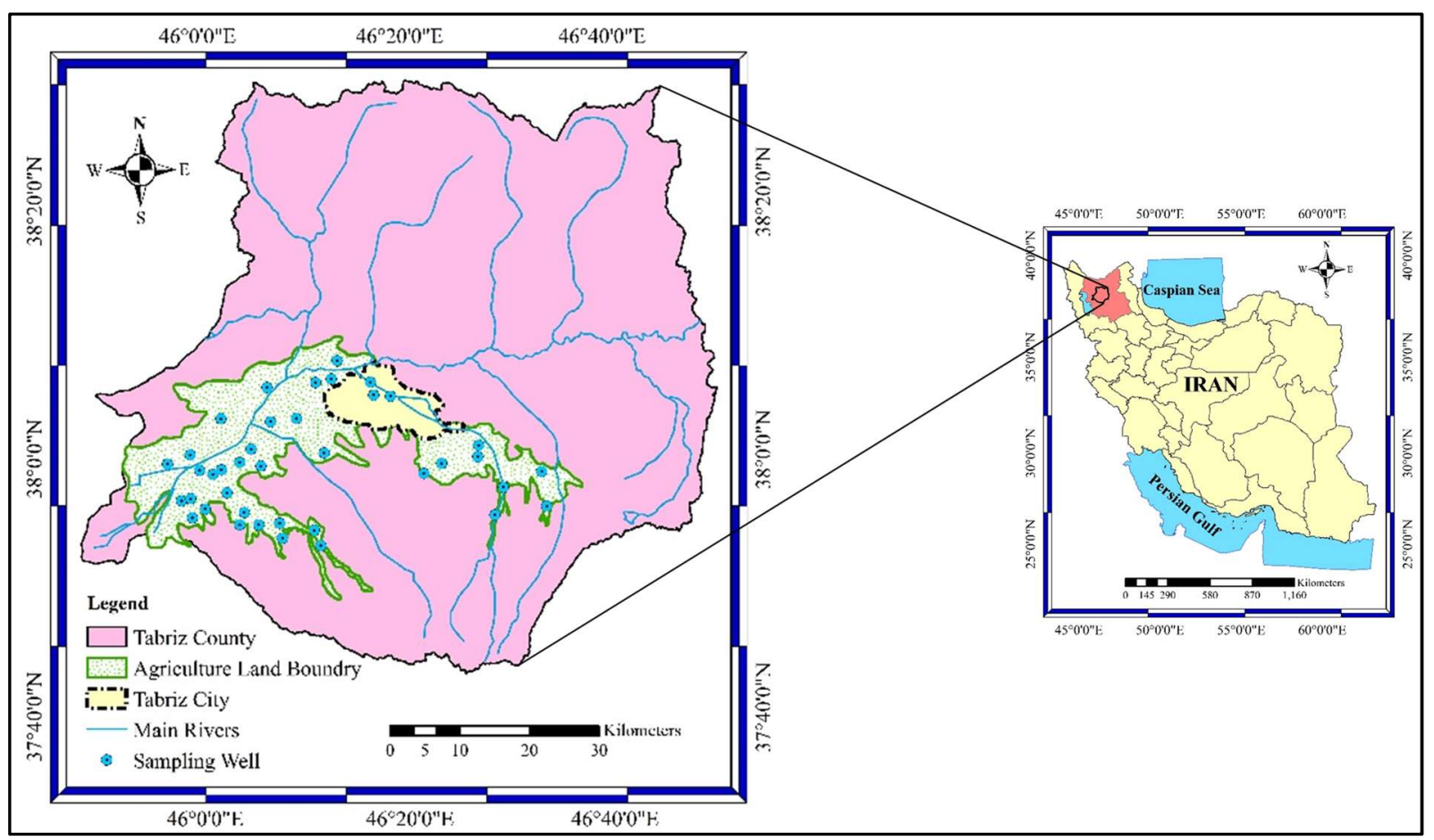

Figure 1. The geographical position of the study area with sites of sampled wells

\section{Data collection}

$\mathrm{EC}$, TDS, $\mathrm{Cl}, \mathrm{Ca}, \mathrm{Mg}, \mathrm{Na}, \mathrm{K}, \mathrm{SO}_{4}, \mathrm{TH}, \mathrm{HCO}_{3}, \mathrm{pH}, \mathrm{CO}_{3}$ and $\mathrm{SAR}$ data were obtained twice in May and September from 39 wells $n$ the period of 2003 to 2014 (Figure 1). A total of 936 samples were utilized for analysis brief statistical parameters of each well in the studied period is presented in Table 1.

Table 1. The statistical properties of the qualitative parameters in Tabriz plain aquifer, during the period between 2003 to 2014

\begin{tabular}{cccccc}
\hline Parameters & Unit & Min & Max & Average & $\begin{array}{c}\text { Standard } \\
\text { Devision }\end{array}$ \\
\hline $\mathrm{SO} 4$ & $(\mathrm{mg} / \mathrm{L})$ & 0.08 & 22.13 & 4.76 & 4.52 \\
$\mathrm{Cl}$ & $(\mathrm{mg} / \mathrm{L})$ & 0.20 & 102.50 & 15.05 & 20.47 \\
$\mathrm{HCO} 3$ & $(\mathrm{mg} / \mathrm{L})$ & 0.58 & 10.97 & 4.05 & 2.07 \\
$\mathrm{Co} 3$ & $(\mathrm{mg} / \mathrm{L})$ & 0.00 & 1.03 & 0.12 & 0.19 \\
$\mathrm{pH}$ & - & 6.35 & 9.45 & 7.91 & 0.58 \\
$\mathrm{EC}$ & $(\mu \mathrm{m} / \mathrm{cm})$ & 186.55 & 11560.00 & 2393.27 & 2406.94 \\
$\mathrm{~K}$ & $(\mathrm{mg} / \mathrm{L})$ & 0.00 & 0.78 & 0.23 & 0.16 \\
$\mathrm{Na}$ & $(\mathrm{mg} / \mathrm{L})$ & 0.44 & 48.25 & 10.85 & 12.58 \\
$\mathrm{Mg}$ & $(\mathrm{mg} / \mathrm{L})$ & 0.25 & 22.60 & 4.97 & 4.76 \\
$\mathrm{Ca}$ & $(\mathrm{mg} / \mathrm{L})$ & 0.80 & 50.00 & 7.93 & 9.34 \\
$\mathrm{TH}$ & $(\mathrm{mg} / \mathrm{L})$ & 31.35 & 3625.00 & 620.24 & 682.19 \\
$\mathrm{TDS}$ & $(\mathrm{mg} / \mathrm{L})$ & 111.93 & 7514.00 & 1550.23 & 1563.50 \\
$\mathrm{SAR}$ & - & 0.40 & 24.83 & 3.91 & 3.89 \\
\hline
\end{tabular}

\section{Irrigation Water Quality}

The form and the amount of the dissolved elements in the irrigation water identify the quality of it. Generally, salinity, specific ion toxicity, trace element toxicity and miscellaneous effect to sensitive crops are utilized for evaluating the quality of irrigation water (Wilcox, 1955). 


\section{Salinity hazard}

In general, under the condition of high electrical conductivity, the crop faces the physiological drought. Usually, waters with EC values lower than $700 \mu \mathrm{S} / \mathrm{cm}$ are categorized as suitable irrigation waters. The arrangement of EC value for organizing irrigation water qualities are presented in Table 2 (Simsek and Gunduz 2007).

Table 2. Classification for IWQ index parameters

\begin{tabular}{|c|c|c|c|c|c|}
\hline Hazard & Weight & Parameter & Range & Rating & Suitability \\
\hline \multirow{3}{*}{ Salinity hazard } & \multirow{3}{*}{5} & \multirow{3}{*}{$\begin{array}{l}\text { Electrical conductivity } \\
\qquad(\mu \mathrm{S} / \mathrm{cm})\end{array}$} & $\mathrm{EC}<700$ & 3 & High \\
\hline & & & $700 \leq \mathrm{EC} \leq 3,000$ & 2 & Medium \\
\hline & & & $\mathrm{EC}>3,000$ & 1 & Low \\
\hline \multirow{2}{*}{$\begin{array}{c}\text { Infiltration and } \\
\text { permeability hazard }\end{array}$} & 4 & See Table 3 for details & & & \\
\hline & \multirow{6}{*}{3} & \multirow{3}{*}{ Sodium adsorption ratio (-) } & $\mathrm{SAR}<3.0$ & 3 & High \\
\hline \multirow{5}{*}{ Specific ion toxicity } & & & $3.0 \leq \mathrm{SAR} \leq 9.0$ & 2 & Medium \\
\hline & & & $\mathrm{SAR}>9.0$ & 1 & Low \\
\hline & & & $\mathrm{CI}<140$ & 3 & High \\
\hline & & Chloride $(\mathrm{mg} / \mathrm{l})$ & $140 \leq \mathrm{CI} \leq 350$ & 2 & Medium \\
\hline & & & $\mathrm{CI}>350$ & 1 & Low \\
\hline \multirow{7}{*}{$\begin{array}{l}\text { Miscellaneous effects to } \\
\text { sensitive cops }\end{array}$} & \multirow{7}{*}{1} & \multirow{3}{*}{ Bicarbonate (mg/l) } & $\mathrm{HCO} 3<90$ & 3 & High \\
\hline & & & $90 \leq \mathrm{HCO} 3 \leq 500$ & 2 & Medium \\
\hline & & & HCO $3>500$ & 1 & Low \\
\hline & & \multirow{4}{*}{$\mathrm{pH}$} & $7.0 \leq \mathrm{pH} \leq 8.0$ & & \\
\hline & & & $6.5 \leq \mathrm{pH}<7.0$ and & $\begin{array}{l}3 \\
2\end{array}$ & High \\
\hline & & & $8.0<\mathrm{pH} \leq 8.5$ & & Medium \\
\hline & & & $\begin{array}{c}\mathrm{pH}<6.5 \text { or } \\
\mathrm{pH}>8.5\end{array}$ & 1 & Low \\
\hline
\end{tabular}

\section{Permeability and infiltration hazard}

Salinity and sodium adsorption ratio (SAR) are the two common factors which affect infiltration. The SAR value of irrigation water is computed as:

$$
S A R=\frac{\left[\mathrm{Na}^{+}\right]}{\sqrt{\frac{\left[\mathrm{Ca}^{++}\right]+\left[\mathrm{Mg}^{++}\right]}{2}}}
$$

Where, $\left[\mathrm{Na}^{+}\right],\left[\mathrm{Ca}^{++}\right]$and $\left[\mathrm{Mg}^{++}\right]$stand for the concentration of sodium, calcium and magnesium particles in water, respectively (Ayers and Westcot, 1985). A grouping of EC-SAR paradigm is exploited to survey the possible risk of penetration in the soil (Simsek and Gunduz, 2007). It has been reported that a high sodium surface is created when the dirt is flooded by waters of high sodium concentration which debilitates the structure of the soil. The soil compresses and after that, it is scattered to minor elements and stops up its pores. Another essential parameter is the content of clay in the soil. When the SAR value gets high and it negatively affects the soil structure because it causes the soil mud particles to scatter (Simsek and Gunduz, 2007). The categorization of water system quality based in its penetration danger is presented in Table 2 .

\section{Toxicity of particular particles}

A number of ions including sodium, chloride and boron are toxic for plants when their concentration gets high in water or in soil. In the moment when the concentrations of the ions in plants are so to cause harm or decrease in the production, they are thought to be toxic. The degree of toxicity is definite to each plant and also it is depended on the uptake amount. The lasting, enduring sort crops are in great danger to this kind of toxicity when contrasted with the yearly harvests (Ayers and Westcot, 1985). Chloride ion can be originated in water system and if it collects in the plants it can diminish yields (FAO, 1994). Chloride at low concentrations is an imperative part of ions to crops, however if the concentration 
values get higher than $140 \mathrm{mg} / \mathrm{l}$ the toxicity starts to develop (Table 2). Signs of damage will be existing as burning of leafs or the drying of leaf tissue. The recognition of toxic sodium concentrations is discreetly troublesome contrasted with the poisonous quality of the other particles. Regular toxicity manifestations on the plants include burning of leafs, dead tissues along the outside edges of leafs as opposed to side effects of chloride toxic concentration which ordinarily starts from the extraordinary leaf tip (Ayers and Westcot, 1985).

\section{Toxicity of trace elements}

It is a fact that basically lants and creatures need trace elements in low concentration as an imperative portion, but higher amounts of these elements are being poisonous for plants and even people. Arsenic, selenium and chromium could become an abundant danger to groundwater supplies (Narany, 2016).

\section{Other effects}

A number of practices such as anthropogenic exercises, farming procedures and utilization of nitrogen fertilizers cause an increase in nitrate of ground waters (FAO, 1994). The alkalinity of water is associated to $\mathrm{pH}$ levels.

Table 3. Classification for infiltration and permeability hazard

\begin{tabular}{|c|c|c|c|c|c|c|c|}
\hline & \multicolumn{5}{|l|}{ SAR } & \multirow{2}{*}{ Rating } & \multirow{2}{*}{ Suitability } \\
\hline & $<3$ & $3-6$ & $6-12$ & $12-20$ & $>20$ & & \\
\hline \multirow[t]{3}{*}{$\mathrm{EC}$} & $>700$ & $>1,200$ & $>1,900$ & $>2,900$ & $>5,000$ & 3 & High \\
\hline & $700-200$ & $1,200-300$ & $1,900-500$ & $2,900-1,300$ & $5,000-2,900$ & 2 & Medium \\
\hline & $<200$ & $<300$ & $<500$ & $<1,300$ & $<2,900$ & 1 & Low \\
\hline
\end{tabular}

\section{Irrigation groundwater quality index (IWQ index)}

The hydrochemical parameters employed for evaluating the irrigation water quality are selected according to Ayers and Westcot (1985) and Simsek and Gunduz (2007). The minimum and maximum weights of 1 and 5 have been allocated to $\mathrm{pH}$ and EC according to their importance on irrigation water quality. Moreover, different weights among 1 and 5 were considered to other hazards due to the significance of their role in irrigation water quality. Furthermore, the scale of rating is altered from 1 as low suitability for irrigation, to 3 as high suitability for irrigation, for every single parameter (Simsek and Gunduz, 2007; Narany, 2016). The suggested IWQ index, which assesses the joint effect of quality parameters is calculated according to Eqs. 2 and 3.

$$
\begin{aligned}
& W_{i}=\frac{w}{N} \sum_{i=1}^{N} R_{i} \\
& I W Q \text { Index }=\sum W_{i}
\end{aligned}
$$

where $\mathrm{W}$ is the involvement of each one of the five mentioned hazards, $\mathrm{w}$ is the weight of each hazard, $\mathrm{N}$ is the total number parameters and $\mathrm{R}$ is the rating value as given in Table 3.

According to the unavailability of all water quality data, four risk groups of Salinity, Infiltration and permeability, particularly ion toxicity and miscellaneous impacts to sensitive cops were implemented to determine the quality of the aquifer used for agricultural dedications in the study zone.

After the estimation of the index value, an appropriate examination is done in light of the three unique classes. The IWQ lower than 19 is specified as low, between 19 and 32 as Medium and higher than 32 as high. The qualities is gotten using several rating factors (i.e., 1, 2 and 3) to every parameter without changing its measuring coefficiency, along these lines yielding three diverse values for index (i.e.,39, 26 
and 13). The average of these values is utilized to set the upper and lower limits which is utilized as a part of every specific classification (Simsek and Gunduz, 2007)

\section{Water Quality Index}

Horton (1965) was the first in representing the quality of groundwater by indices. WQI is among the numerous tools for representing the data on the nature of water (Naik and Purohit, 2001).WQI is characterized as a rating which indicates the impact of several parameters on the general nature of water (Sahu and Sikdar, 2008). In that capacity, it is a significant marker for the evaluation and administration of groundwater. WQI is assessed in light of the appropriateness of groundwater for human utilization.

Three stages are done for calculating WQI. In the initial step, weight $\left(\mathrm{w}_{\mathrm{i}}\right)$ of each water quality parameter is measured as indicated by its significance in the general nature of water for drinking purposes. At that point, the relative weight $\left(\mathrm{W}_{\mathrm{i}}\right)$ is figured by $\mathrm{Eq}(4)$ by the following formula (Singh, 1992):

$$
W_{i}=\frac{w_{i}}{\sum_{i=1}^{n} w_{i}}
$$

In the formula above, $\mathrm{n}$ is the quantity of parameters. In the second step, a rating of quality $\left(\mathrm{q}_{\mathrm{i}}\right)$ is ascertained for every parameter, and the ratio of its individual standard value is measured based on the rules from the WHO (2011):

$$
q_{i}=\left(\frac{C_{i}}{S_{i}}\right) \times 100
$$

In the formula above, $C_{i}$ is the concentration of chemical parameters for water samples which is expressed in $\mathrm{mg} / \mathrm{L}$, and $\mathrm{Si}$ is the WHO's standard of drinking water for every substance parameter in $\mathrm{mg} / \mathrm{L}$. In the third step, the WQI is measured as (Tiwari and Mishra, 1985):

$$
W Q I=\sum_{i=1}^{n} W_{i} q_{i}
$$

Values of WQI are usually processed and then grouped into five excellent, good, poor, very poor and inappropriate classes of water for drinking (Table 4) (Ramakrishnaiah et al., 2009).

Table 4. Water quality classification based on WQI value

\begin{tabular}{ccc}
\hline & \multicolumn{2}{c}{ Classification of drinking water quality } \\
\hline WQI Range & Class & Type of water \\
\hline below 50 & I & Excellent water \\
$50-100$ & II & Good water \\
$100-200$ & III & Poor water \\
$200-300$ & IV & Very poor water \\
above 300 & V & Water unsuitable for \\
& & drinking \\
\hline
\end{tabular}

12 parameters were included in calculating WQI by the weighted arithmetic technique. Standard of WHO for drinking water for every chemical parameter by the rules of WHO (2011) are recorded in Table 5. Every parameter has a weight as for its significance for the nature of water for drinking purposes, and 5 is the maximum weight which stands for the total dissolved solids (TDS) and EC; weight of 4 is allocated to $\mathrm{SO}_{4}$ and $\mathrm{TH}$; weight of 3 is alloted to $\mathrm{pH}, \mathrm{Cl}$ and $\mathrm{Na}$; and weight of 2 is appointed to $\mathrm{K}, \mathrm{Mg}$, $\mathrm{Ca}, \mathrm{CO}_{3}$ and $\mathrm{HCO}_{3}$. 
Table 5. Desirable limits of parameters and assigned relative weight

\begin{tabular}{|c|c|c|c|c|}
\hline Parameters & $\begin{array}{l}\text { WHO desirable } \\
\text { limit }(\mathrm{mg} / \mathrm{L})\end{array}$ & $\begin{array}{l}\text { WHO allowable } \\
\text { limit }(\mathrm{mg} / \mathrm{L})\end{array}$ & Weight $\left(w_{i}\right)$ & $\begin{array}{c}\text { Relative } \\
\text { Weight }\left(\mathrm{W}_{\mathrm{i}}\right)\end{array}$ \\
\hline TDS & $500(\mathrm{mg} / \mathrm{L})$ & $1,000(\mathrm{mg} / \mathrm{L})$ & 5 & 0.135 \\
\hline $\mathrm{pH}$ & $6.5-8.5$ & 8.5 & 3 & 0.081 \\
\hline $\mathrm{EC}$ & $1,500 \mu \mathrm{s} / \mathrm{cm}$ & $1,500 \mu \mathrm{s} / \mathrm{cm}$ & 5 & 0.135 \\
\hline $\mathrm{TH}$ & $300(\mathrm{mg} / \mathrm{L})$ & $600(\mathrm{mg} / \mathrm{L})$ & 4 & 0.108 \\
\hline $\mathrm{Ca}$ & $75(\mathrm{mg} / \mathrm{L})$ & 75 (mg/L) & 2 & 0.054 \\
\hline $\mathrm{Na}$ & $200(\mathrm{mg} / \mathrm{L})$ & $200(\mathrm{mg} / \mathrm{L})$ & 3 & 0.081 \\
\hline $\mathrm{Mg}$ & $30(\mathrm{mg} / \mathrm{L})$ & $30(\mathrm{mg} / \mathrm{L})$ & 2 & 0.054 \\
\hline $\mathrm{K}$ & $10(\mathrm{mg} / \mathrm{L})$ & $10(\mathrm{mg} / \mathrm{L})$ & 2 & 0.054 \\
\hline $\mathrm{CL}$ & $200(\mathrm{mg} / \mathrm{L})$ & $200(\mathrm{mg} / \mathrm{L})$ & 3 & 0.081 \\
\hline $\mathrm{CO}_{3}$ & $100(\mathrm{mg} / \mathrm{L})$ & $100(\mathrm{mg} / \mathrm{L})$ & 2 & 0.054 \\
\hline
\end{tabular}

\section{Results and Discussion}

WQI index computed for 24 periods of May and September between, 2003 and 2014, respectively. The minimum value for WQI index in these 24 periods of time was equal to 12.14 and the maximum value was equal to 300.53. Regression equation between WQI index and time ( $t$ ) was obtained in order to assess WQI index general procedures in each of the wells studied. (Table 6).

Table 6. The linear regression equation between WQI index and time from 2003 to 2014

\begin{tabular}{clcl}
\hline Well Number & regression equation & Well Number & regression equation \\
\hline 1 & WQI $=0.48 t+17.92$ & 21 & WQI $=-0.29 t+29.88$ \\
2 & WQI $=1.91 t+4.54$ & 22 & WQI $=0.95 t+17.08$ \\
3 & WQI $=-0.15 t+48.38$ & 23 & WQI $=1.86 t+37.59$ \\
4 & WQI $=-0.03 t+19.16$ & 24 & WQI $=0.05 t+17.43$ \\
5 & WQI $=1.01 t+8.92$ & 25 & WQI $=-1.28 t+177.42$ \\
6 & WQI $=0.88 t+14.60$ & 26 & WQI $=-1.16 t+151.8$ \\
7 & WQI $=1.18 t+174.63$ & 27 & WQI $=-1.16 t+98.29$ \\
8 & WQI $=0.72 t+42.66$ & 28 & WQI $=-1.28 t+168.65$ \\
9 & WQI $=0.17 t+71.64$ & 29 & WQI $=2.06 t+27.58$ \\
10 & WQI $=1.67 t+108.24$ & 30 & WQI $=0.47 t+59.95$ \\
11 & WQI $=-0.02 t+18.90$ & 31 & WQI $=0.47 t+21.29$ \\
12 & WQI $=-0.02 t+22.01$ & 32 & WQI $=-0.20 t+54.52$ \\
13 & WQI $=0.48 t+135.20$ & 33 & WQI $=-0.001 t+17.22$ \\
14 & WQI $=-0.61 t+62.01$ & 34 & WQI $=0.13 t+15.05$ \\
15 & WQI $=-0.54 t+116.15$ & 35 & WQI $=-0.57 t+79.78$ \\
16 & WQI $=-0.074 t+24.17$ & 36 & WQI $=-2.43 t+139$ \\
17 & WQI $=3.19 t+195.82$ & 37 & WQI $=-0.08 t+17.75$ \\
18 & WQI $=0.56 t+52.49$ & 38 & WQI $=-0.06 t+14.69$ \\
19 & WQI $=-0.62 t+77.68$ & 39 & WQI $=2.54 t+71.97$ \\
20 & WQI $=0.50 t+24.38$ & & \\
\hline
\end{tabular}

According to Table 6 WQI index value has decreased in 19 wells, while in other wells an increasing trend can be concluded. The decreased WQI index procedure shows an enhancement in drinking groundwater, while an increasing trend shows reduction of drinking groundwater quality. Of the 936 samples obtained from 39 wells in the period between 2003 to 2014, 497 water samples were categorized as 'excellent water', 217 water samples were classified as 'good water', 188 water samples were classified as 'poor water', 31 water samples were classified as 'very poor water' and 3 water samples were classified as 'unsuitable water for drinking'. The average value of the WQI index was determined after calculating 
the area of Thiessen polygons for each of the 39 studied wells according to the area affected by each of the wells of. Figure 2a displays the average WQI index in the study area during the statistical period. According to this figure, WQI index of the area has an increasing trend. In fact, the quality of groundwater for drinking has been decreased over the time. Despite the decline in the quality of drinking groundwater, the average WQI index of aquifer still is in 'good water' class over the study time. Therefore, a serious and distributive risk of inappropriate water quality cannot be confirmed for the aquifer which is supplying urban and rural water.

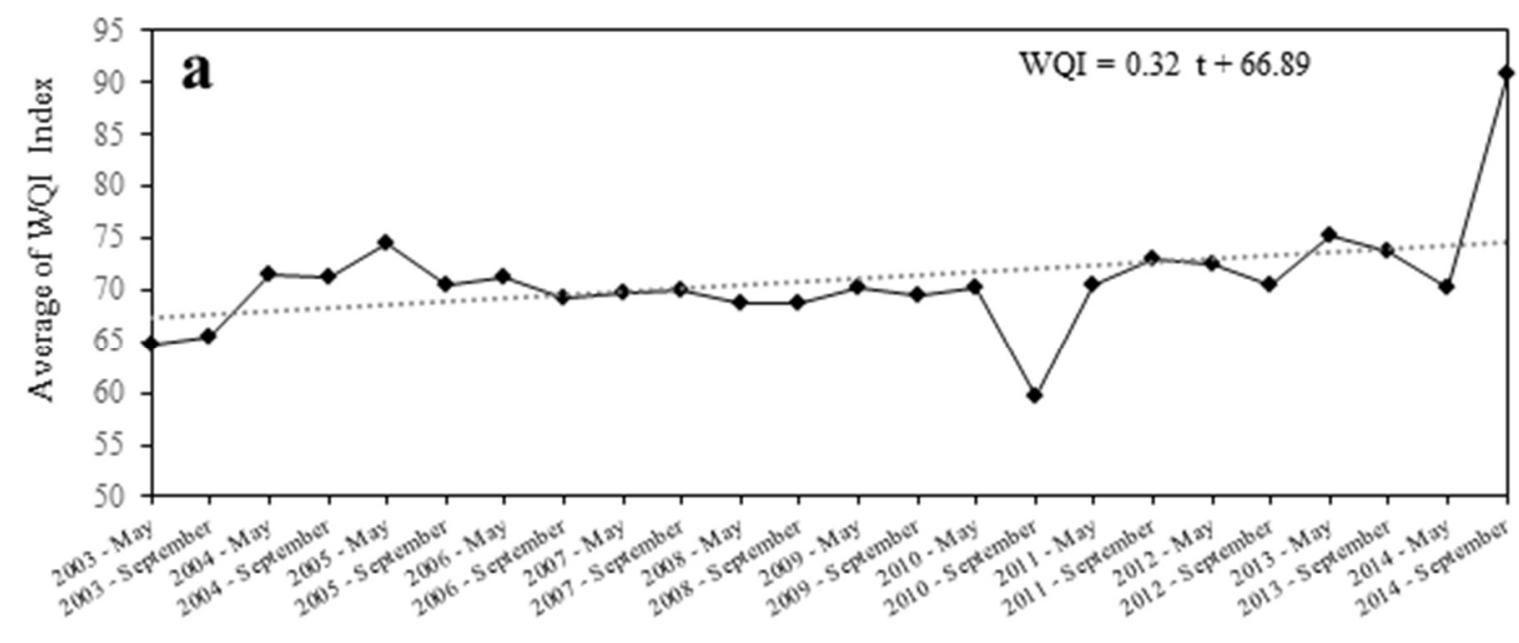

Time

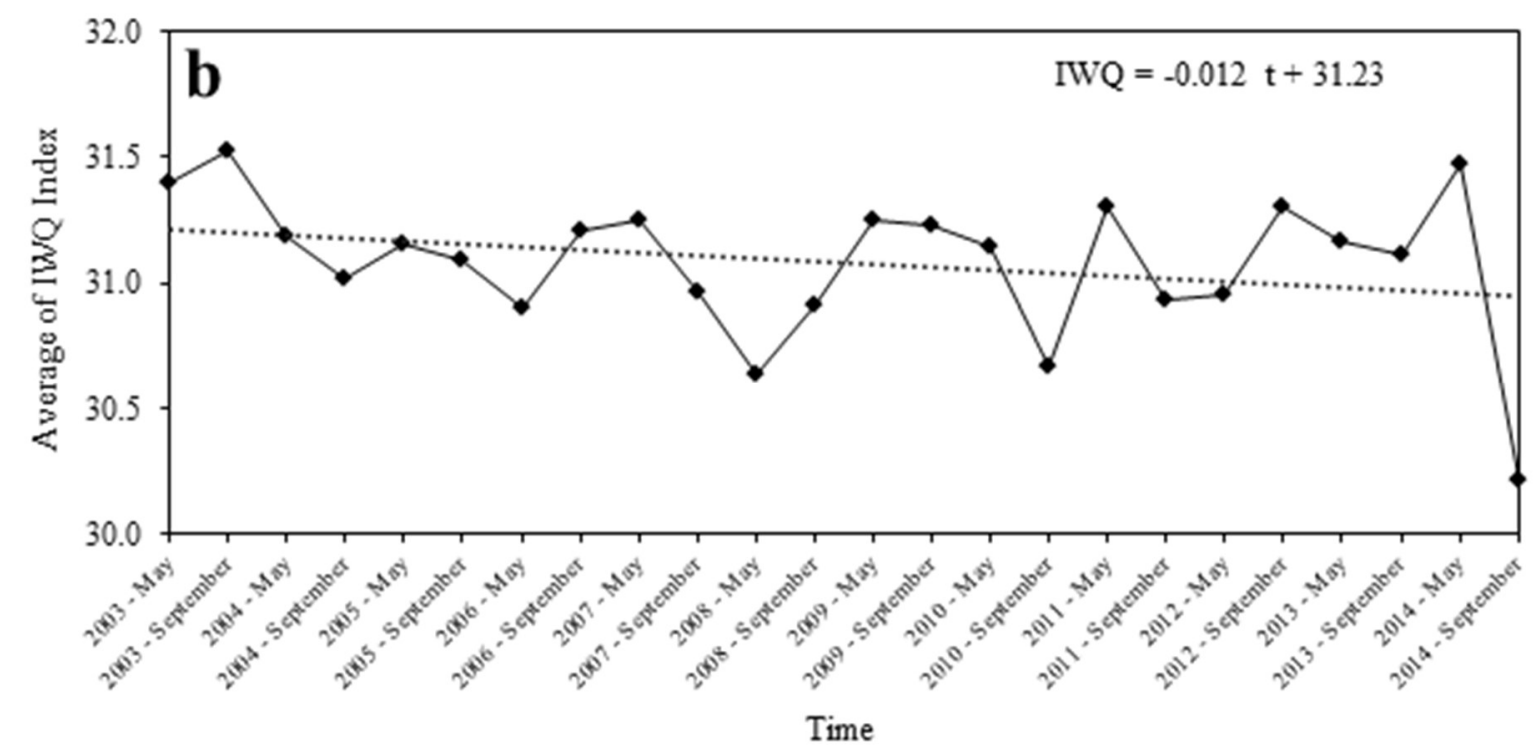

Figure 2. Moderate gradual changes in the WQI and IWQ indexes in the entire study area

Seventy out of 81 wells supplying urban drinking water are classified as 'excellent water' and the rest of the wells are classified as 'good water' (Figure 3a). 27 out of 50 wells supplying rural drinking water are classified as 'excellent water', 19 are marked as 'good water' and 4 wells are in class of 'poor water'. According to the results, the condition of urban drinking water wells is very good. But the situation of 4 rural drinking water wells is not appropriate and the position of the wells or the water source of the villages covered by these 4 wells should be changed. Therefore, generally the position of the urban and rural water wells has been chosen carefully. It is recommended that drinking water is supplied from 
South and Eastern areas of the study range which are the main areas feeding the aquifer and has very good water quality.

Salinity and Permeability and infiltration hazard weights equal to 5 and 4, respectively, have the greatest impact on agricultural water quality index. Spatial distribution of electrical conductivity average measured in 39 wells is shown in Figure 3b. Aquifer feeding regions which mostly include the south and eastern parts of the study area have the lowest amount of EC, and the closer to the center of the study area, the increase in the EC values (Figure 3b). Mosaedi et al. (2017) showed that the central regions of Tabriz plain have high salinity and the eastern regions have low salinity. The quality of underground water in the central regions of Tabriz plain is more undesirable than the aquifer feeding areas (Barzegar et al. 2015).

$18 \%$ of the total area has EC amount less than $700(\mu \mathrm{s} / \mathrm{cm})\left(143 \mathrm{~km}^{2}\right), 48 \%$ of the area has more EC than $3000(\mu \mathrm{s} / \mathrm{cm})\left(380 \mathrm{~km}^{2}\right)$ and 34 percent $\left(268 \mathrm{~km}^{2}\right)$ has EC between 700 to $3000(\mu \mathrm{s} / \mathrm{cm})$.

The highest and lowest average amount of SAR is respectively 0.69 and 14.96 (Figure 3c). SAR amount is low in the aquifer feed zone as well as the EC, and it will increase as getting close to the North and West of the aquifer.

Studies have shown that groundwater quality in the aquifer feeding areas of Tabriz plain is better than other areas of this plain (Jeihouni et al. 2014; Barzegar et al., 2015).

The study area is classified as Hazard from the the infiltration and permeability aspect (Table 3 and Figure 3d). Increased amount of EC and SAR values in a region can neutralizes the negative effects of each parameter (Table 3). Therefore, due to the large quantities of EC and SAR in central, northern and western region of the study area, infiltration and permeability hazard in these areas are low. According to Figure $3 \mathrm{~d}$, the average 4.21 percent of the area $\left(33 \mathrm{~km}^{2}\right)$ was rated 1 to 2 and 95.79 percent $\left(758 \mathrm{~km}^{2}\right)$ of the region was rated 2 to 3 . In fact, agricultural water in this area is not a limiting factor for infiltration and permeability hazard.

IWQ index for the 24 periods, the months of May and September 2003 and 2014 was calculated in the study. IWQ lowest index value in the 24 periods was 21 and the maximum was 35 . Area IWQ index average was calculated based on the area of Thiessen polygons corresponding to each of the wells. IWQ index change trend over the time is shown in Figure 2b. According to this figure, IWQ index is suitable over the time in terms of climate adaptation for farming in the area. Very little negative IWQ indicator over the time suggests the sustainability of groundwater quality for agricultural purposes in the study area as well. For maintaining the quality of the aquifer, necessary measures should be taken in order to eliminate the negative trend, and then progress to a positive trend for the IWQ index be done. The values of IWQ varies from 25.9 to 34.55 for the whole region (Figure 3e). According to the abovementioned ranges, the values of IWQ in Figure 3e suggest that about 37 percent $\left(296 \mathrm{~km}^{2}\right)$ of groundwater in the study area has high compatibility and the remaining 63 percent $\left(495 \mathrm{~km}^{2}\right)$ has a moderate adaptation for agricultural purposes. The results also show that 2227 agricultural wells harvest groundwater with medium Suitability and 1657 agricultural wells harvest groundwater with high Suitability. 

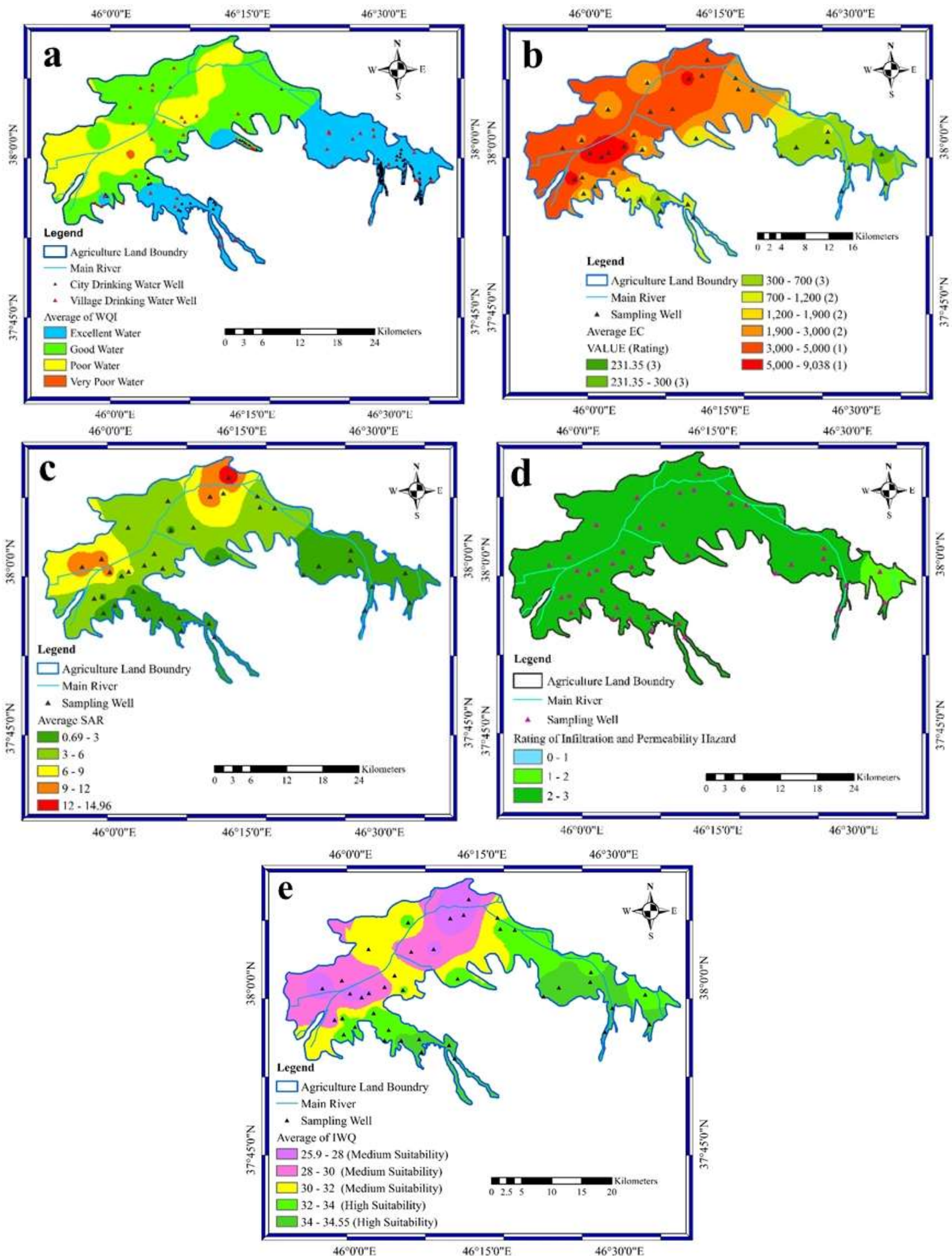

Figure 3. Geographical distribution of studied parameters in the study area

\section{Conclusions}


This study disclosed that the use of indicators for evaluating the quality of groundwater can provide a good general overview to water and environmental managers in order to make better management decisions on Tabriz aquifer. WQI and IWQ indexes offer suitable areas for harvesting drinking and agricultural water, respectively. The suitability of water taken from wells in the study area by the type of application is also determined using these indexes. Therefore, water and environmental managers can use drinking and agricultural water suitability maps to change the inappropriate wells location. Agriculture managing organizations can also determine the type, amount, and irrigation of each region's products based on the suitability of groundwater in that area in order to increase the production and maintain the stability of soil type. The results showed that in terms of consistency, the most urban and rural water wells were classified as 'excellent water' and 'good water'. Due to the agricultural water compatibility zoning map in the study area, there is no low suitability range, and the area has high and medium suitability groundwater for agricultural purposes. The WQI and IWQ index changes over the time in the study area show the decrease in groundwater quality for drinking and agriculture purposes, respectively. Water contamination can be controlled by limiting natural, farming run-off and urban land utilize contamination.

\section{Acknowledgments}

This paper is published as part of a research project supported by the University of Tabriz Research Affairs Office.

\section{REFERENCES}

Hashmi, I., Farooq, S., \& Qaiser, S. (2009). Chlorination and water quality monitoring within a public drinking water supply in Rawalpindi Cantt (Westridge and Tench) area, Pakistan. Environmental monitoring and assessment, 158(1-4), 393-403.

FAO (1994). Water quality for agriculture. Food and Agriculture Organization of the United Nations Rome.

Tlili-Zrelli B, Azaza FH, Gueddari M, Bouhlila R (2013). Geochemistry and quality assessment of groundwater using graphical and multivariate statistical methods. A case study: Grombalia phreatic aquifer (Northeastern Tunisia). Arabian Journal of Geosciences 6(9):3545-3561.

Venkateswaran S, Vijay Prabhu M, Mohammed Rafi M, Vallel LK (2011). Assessment of groundwater quality for irrigational use in Cumbum Valley, Madurai District, Tamil Nadu, India. Nature, Environment and Pollution Technology, 10(2), 207-212.

Jafar Ahamed A, Loganathan K, Ananthakrishnan S (2013). A comparative evaluation of groundwater suitability for drinking and irrigation purposes in Pugalur area, Karur district, Tamilnadu, India. Arch Appl Sci Res 5(1):213-223.

Khan RA, Juahir H, Yusoff MK, Zain SM, TI TH (2012) Using principal component scores and artificial neural networks in predicting water quality index. INTECH Open Access Publisher 271(1-4):283300.

Salahat M, Al-Qinna M, Mashal K, Hammouri M (2014) Identifying major factors controlling groundwater quality in semiarid area using advanced statistical techniques. Water Resour Manag 28(11):3829-3841.

Arumugam K, Elangovan K (2009) Hydrochemical characteristics and groundwater quality assessment in Tirupur region, Coimbatore district, Tamil Nadu, India. Environ Geol 58:1509-1520.

Amiri V, Rezaei M, Sohrabi N (2014) Groundwater quality assessment using entropy weighted Water Quality Index (EWQI) in Lenjanat, Iran. Environ Earth Sci 72:3479-3490. 
Mohebbi MR, Saeedi R, Montazeri A, Azam Vaghefi K, Labbafi S, Oktaie S, Abtahi M, Mohagheghian A (2013) Assessment of water quality in groundwater resources of Iran using a modified drinking water quality index (DWQI). Ecol Indic 30:28-34.

Saeedi M, Abessi O, Sharifi F, Meraji M (2010) Development of groundwater quality index. Environ Monit Assess, 163(1), 327-335.

Tanji, K. K. (1990). Agricultural Salinity Assessment and Management, American Society of Civil Engineers. Manuals and Reports on Engineering Practice Number 71, 619 p.

Kwiatkowski, J., Marciak, L. C., Wentz, D., \& King, C. R. (1995). Salinity mapping for resource management within the County of Wheatland, Alberta, Conservation and Development Branch, Alberta Agriculture, Food and Rural Development, Edmonton, $22 \mathrm{p}$.

Ayers, R. S., \& Westcot, D. W. (1985). Water quality for agriculture, FAO Irrigation and Drainage Paper No. 29, Rev. 1, U. N. Food and Agriculture Organization, Rome.

Adhikari P, Shukla MK, Mexal JG, Sharma P (2011) Assessment of the soil physical and chemical properties of desert soils irrigated with treated wastewater using principal component analysis. Soil Sci. 176(7):356-366.

Debels P, Figueroa R, Urrutia R, Niell X (2005) Evaluation of water quality in the Chillan River (Central Chile) physicochemical parameters and modified water quality index. Environ Monit Assess 110: 301-322.

Narany TS, Ramli MF, Aris AZ, Sulaiman WNA, Fakharian K (2014). Spatiotemporal variation of groundwater quality using integrated multivariate statistical and geostatistical approaches in Amol-Babol plain, Iran. Environ Monit Assess 186(9):5797-5815.

Horton, R. K. (1965). An index number system for rating water quality. Journal of Water Pollution Control Federation, 37, 300-306.

Simos FS, Moriera AB, Bisinoti MC, Gimenez SMN, Yabe MJS (2008) Water Quality Index as a simple indicator of aquaculture effects on aquatic bodies. Ecol Ind 8(5):476-484.

Effendi, H., \& Wardiatno, Y. (2015). Water quality status of Ciambulawung River, Banten Province, based on pollution index and NSF-WQI. Procedia Environmental Sciences, 24, 228-237.

Bodrud-Doza Md, Towfiqul Islam ARM, Ahmed F, Samiran D, Narottam S, Safiur Rahman M (2016) Characterization of groundwater quality using water evaluation indices, multivariate statistics and geostatistics in central Bangladesh. Water Sci 30(1):19-40

Nampak H, Pradhan B, Manap MA (2014) Application of GIS based data driven evidential belief function model to predict groundwater potential zonation. J Hydrol 513:283-300

Manap MA, Nampak H, Pradhan B, Lee S, Sulaiman WNA, Ramli MF (2014) Application of probabilistic-based frequency ratio model in groundwater potential mapping using remote sensing data and GIS. Arab J Geosci 7(2):711-724.

Barzegar, R., Moghaddam, A. A., \& Kazemian, N. (2015). Assessment of heavy metals concentrations with emphasis on arsenic in the Tabriz plain aquifers, Iran. Environmental Earth Sciences, 74(1), 297-313.

Asghari Moghaddam A, Allaf Najib M (2006) Hydrogeologic characteristics of the alluvial tuff aquifer of northern Sahand Mountain slopes, Tabriz, Iran. Hydrogeol J 14(7):1319-1329

Wilcox, L. V. (1955). Classification and use of the irrigation waters, U.S. Department of Agriculture Circular No. 969, Washington, District of Columbia, 19 p.

Simsek C, Gunduz O (2007) IWQ index: a GIS-integrated technique to assess irrigation water quality. Environ Monit Assess 128(1):277-300.

Jeihouni, M., Toomanian, A., Shahabi, M., \& Alavipanah, S. K. (2014). Groundwater quality assessment for drinking purposes using GIS modelling (case study: city of Tabriz). The International Archives of Photogrammetry, Remote Sensing and Spatial Information Sciences, 40(2), 163. 
Naik S, Purohit KM (2001) Studies on water quality of river Brahmaniin Sundargarh district, Orissa. Indian Journal of Environment and Ecoplanning 5(2):397-402

Sahu P, Sikdar PK (2008) Hydrochemical framework of the aquifer in and around East Calcutta wetlands, West Bengal. Indian Environmental Geology 55(4):823-835

Tiwari TN, Mishra MA (1985). A preliminary assignment of water quality index of major Indian rivers. Indian J Environ Protect 5(4):276-279.

Singh DF (1992) Studies on the water quality index of some major rivers of Pune, Maharashtra. Proceedings of the Academy of Environmental Biology 1(1):61-66.

WHO (2011) Hardness in drinking-water background document for development of WHO guidelines for drinking-water quality. World health Organization, Geneva, $19 \mathrm{pp}$.

Ramakrishnaiah C, Sadashivaiah C, Ranganna G (2009) Assessment of water quality index for the groundwater in tumkur taluk, Karnataka state, India. Journal of Chemistry 6(2):523-530.

Negm AM and Armanuos AM. 2016. GIS-Based Spatial Distribution of Groundwater Quality in the Western Nile Delta, Egypt. Hdb Env Chem, DOI 10.1007/698_2016_66.

Zarghami M and Akbariyeh S. 2012. System dynamics modeling for complex urban water systems: Application to the city of Tabriz, Iran. Resources, Conservation and Recycling, 60: 99-106.

Narany TS, Ramli MF, Fakharian K and Aris AZ. 2016. A GIS-index integration approach to groundwater suitability zoning for irrigation purposes. Arab J Geosci, 9(7), 1-15.

Schneider, V. E., Marques, R. V., Bortolin, T. A., Cemin, G., \& Dos Santos, G. M. (2016). Monitoring and assessment of surface water quality in Taquari-Antas Watershed, South Brazil-region with intensive pig farming. Environmental monitoring and assessment, 188(11), 617.

Fijani, E., Moghaddam, A. A., Tsai, F. T. C., \& Tayfur, G. (2017). Analysis and assessment of hydrochemical characteristics of Maragheh-Bonab Plain aquifer, Northwest of Iran. Water Resources Management, 31(3), 765-780.

Khan, A., \& Qureshi, F. R. (2018). Groundwater Quality Assessment through Water Quality Index (WQI) in New Karachi Town, Karachi, Pakistan. Asian Journal of Water, Environment and Pollution, 15(1), 41-46.

Chen, Z., Zhu, Z., Yin, L., Wei, S., \& Deng, L. (2015). The changing water quality characteristics from urban drinking water sources in Guangdong, China. Water resources management, 29(4), 987-1002.

Oyinkuro, O. A., \& Rowland, E. D. (2018). Spatial Groundwater Quality assessment by WQI and GIS in Ogbia LGA of Bayelsa State, Nigeria. Asian Journal of Physical and Chemical Sciences, 4, 1-12. DOI: 10.9734/ajopacs/2017/39055

Vaezihir, A., \& Tabarmayeh, M. (2015). Total vulnerability estimation for the Tabriz aquifer (Iran) by combining a new model with DRASTIC. Environmental Earth Sciences, 74(4), 2949-2965.

Barzegar, R., Moghaddam, A. A., \& Tziritis, E. (2017). Hydrogeochemical features of groundwater resources in Tabriz plain, northwest of Iran. Applied Water Science, 7(7), 3997-4011.

Mosaedi, A., Sough, M. G., Sadeghi, S. H., Mooshakhian, Y., \& Bannayan, M. (2017). Sensitivity analysis of monthly reference crop evapotranspiration trends in Iran: a qualitative approach. Theoretical and applied climatology, 128(3-4), 857-873.

Ramakrishnaiah, C. R., Sadashivaiah, C., \& Ranganna, G. (2009). Assessment of water quality index for the groundwater in Tumkur Taluk, Karnataka State, India. Journal of Chemistry, 6(2), 523-530. 